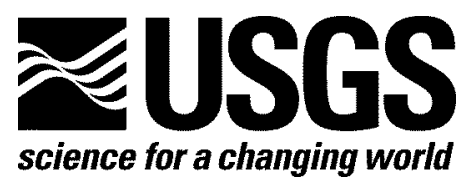

\author{
Alaska Science Center
}

\title{
Geoscience for Alaska's D-1 Lands: A Preliminary Report
}

By J.M. Schmidt, B.M. Gamble and K.A. Labay

Open-File Report 2007-1286

U.S. Department of the Interior

U.S. Geological Survey 


\title{
U.S. Department of the Interior \\ DIRK KEMPTHORNE, Secretary
}

\author{
U.S. Geological Survey \\ Mark D. Myers, Director
}

U.S. Geological Survey, Reston, Virginia 2007

For product and ordering information:

World Wide Web: http://www.usgs.gov/pubprod

Telephone: 1-888-ASK-USGS

For more information on the USGS - the Federal source for science about the Earth, its natural and living resources, natural hazards, and the environment:

World Wide Web: http://www.usgs.gov

Telephone: 1-888-ASK-USGS

Suggested citation:

Schmidt, J.M., Gamble, B.M., and Labay, K.A., 2007, Geoscience for Alaska's D-1 Lands: A Preliminary Report: U.S. Geological Survey Open File Report 2007-1286, 20 p;

http://pubs.usgs.gov/of/2007/1286/

Any use of trade, product, or firm names is for descriptive purposes only and does not imply endorsement by the U.S. Government.

Although this report is in the public domain, permission must be secured from the individual copyright owners to reproduce any copyrighted material contained within this report. 


\section{Contents}

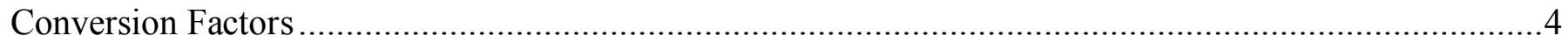

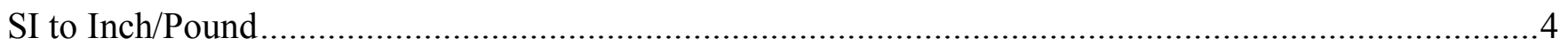

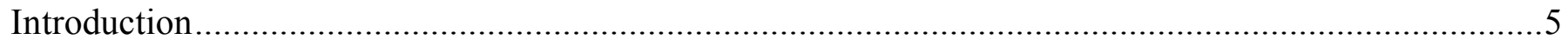

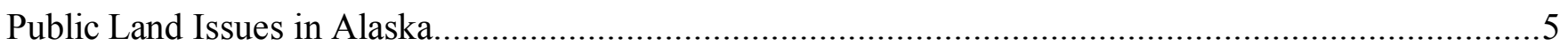

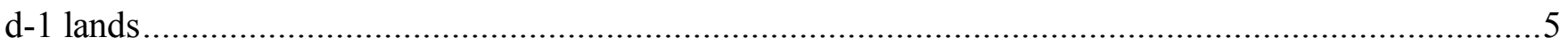

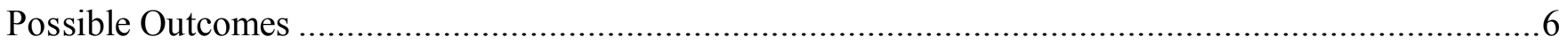

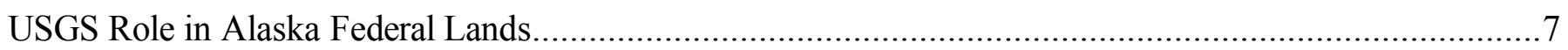

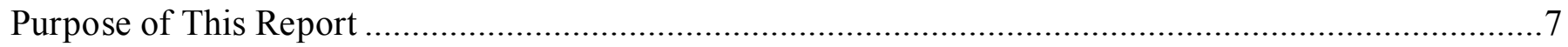

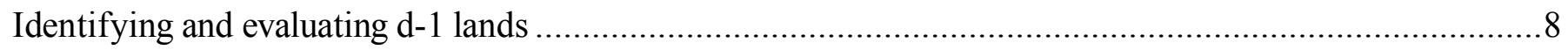

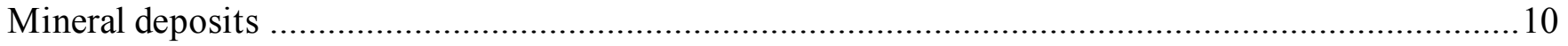

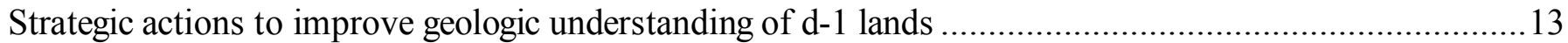

Action 1) Compile data related to access, infrastructure, and land use .................................................. 14

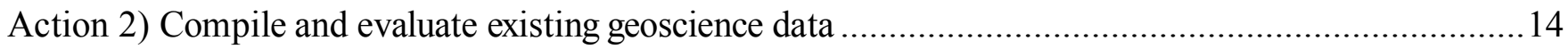

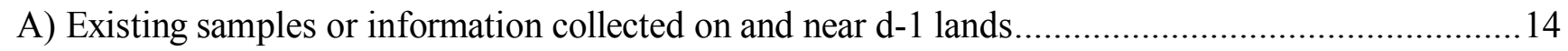

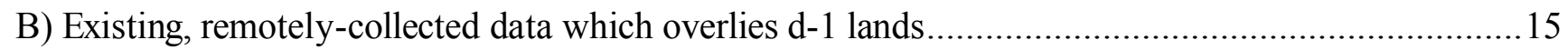

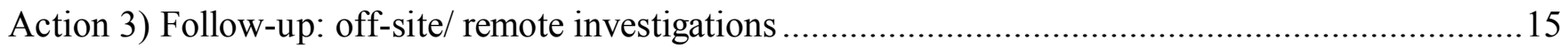

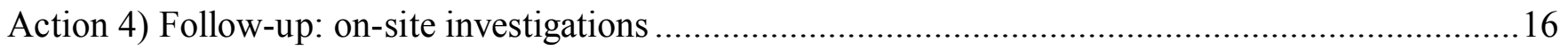

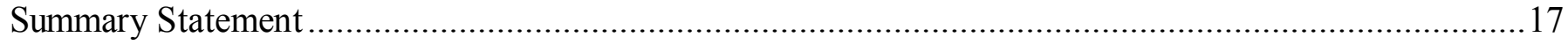

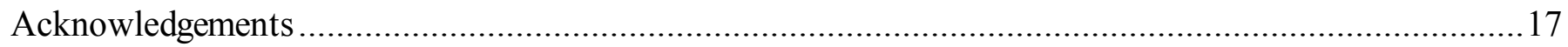

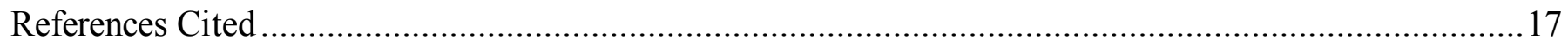

Appendix 1: Procedures used for delineating d-1 lands from BLM GIS databases ..................................19

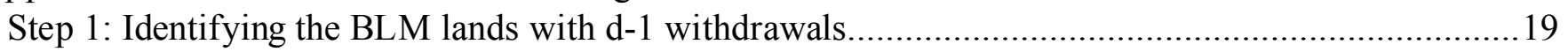

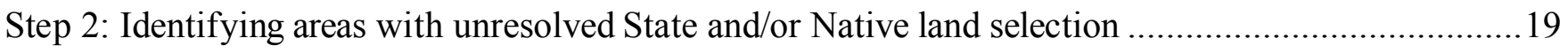

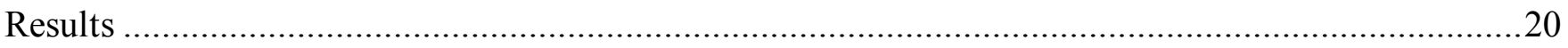

\section{Figures}

Figure 1. (oversized) Topographic map of mainland Alaska, showing extent of BLM d-1 lands (in red and blue); Federal Conservation System Units (CSUs) and other areas closed to mineral entry (in green); d-1 lands Areas of Interest identified in this report (lettered ovals); major towns and villages; $1^{\circ} \times 3^{\circ}$ quadrangle boundaries and names; and known mines, prospects and mineral occurrences (USGS, 2005) within the areas of interest. (hyperlinked)

Figure 2. Map of mainland Alaska showing d-1 areas of interest (ovals) and physiographic provinces as defined by Wahrhaftig (1994).

Figure 3. Map of mainland Alaska, showing $d-1$ areas of interest (red ovals) and labeled mining district boundaries and delineated by Ransome and Kerns (1954). 


\section{Tables}

Table 1.Ownership of d-1 lands in Alaska, pending settlement of Native and State land claims. .... 8

Table 2. Mines, prospects, and mineral occurrences on d-1 lands and in Areas of Interest (data from Alaska Resource Data Files, USGS, 2005). .................................................................... 12

Table 3.Mineral deposit types referenced in this report ...................................................... 13

\section{Conversion Factors}

SI to Inch/Pound

\begin{tabular}{lll}
\hline \multicolumn{1}{c}{ Multiply } & By & To obtain \\
\hline Length & & \\
\hline kilometer $(\mathrm{km})$ & 0.6214 & mile $(\mathrm{mi})$ \\
\hline Area & & \\
\hline square kilometer $\left(\mathrm{km}^{2}\right)$ & 247.1 & acre \\
\hline
\end{tabular}




\section{Geoscience for Alaska's D-1 Lands: A Preliminary Report}

By J.M. Schmidt, B.M. Gamble, and K.A. Labay ${ }^{1}$

\section{Introduction}

\section{Public Land Issues in Alaska}

The Alaska Statehood Act of 1959 began a long process of land selection, claims, and settlement that is still incomplete. It authorized the newly formed State of Alaska to select 104 million of the 365.5 million acres in Alaska as its land entitlement. Subsequent Native claims for land were addressed by the 1971 Alaska Native Claims Settlement Act (ANCSA), which established village and regional Native corporations. These corporations were given the right to select 38 million acres from an available pool of 115 million Federal acres, which, along with existing Native-controlled lands, would result in a total of 43.7 million acres under Native ownership. After passage of these Acts, the State of Alaska and regional and village Native corporations selected lands for conveyance by the Federal government. These lands are in the process of being prioritized, surveyed, and conveyed to the appropriate landowners; this process is nearing completion as the $50^{\text {th }}$ anniversary of Alaskan Statehood approaches. Upon completion, approximately $59 \%$ of Alaska (215 million acres) will remain under Federal control.

\section{d-1 lands}

Following the passage of ANCSA,

"The series of Public Land Orders (PLOs) issued from 1972 to 1975, signed by the Secretary of the Interior under the authority of Section 17(d)(1) of the Alaska Native Claims Settlement Act (ANCSA) withdrew and reserved lands for study and classification. These d-1 PLOs closed the lands to disposal and appropriation under the public land laws (including mining and mineral leasing laws)..... The intent was to limit appropriations of the land in order to complete inventories of resources and assessment of values which would allow for orderly development of land use and management objectives for present and future public needs. In the 1980's pursuant to Section 1008 of Alaska National Interest Lands Conservation Act (ANILCA), some limited studies and environmental assessments were done and about 10 million acres of the land withdrawn by the d-1 PLOs were opened to entry. No further openings have been offered since that time.... As land ownership patterns become more stable, pressure on BLM has been increasing from the State of Alaska, local governments, Native 
corporations, and development interest groups to expedite the opening of lands affected by these PLOs...." (U.S. Bureau of Land Management, 2006)

As a result of increasing public and governmental interest and concern over the progress of the conveyance process, the Alaska Land Transfer Acceleration Act (ALTAA) of December 10, 2004, PL 108-45, provided a mechanism and timetable for resolving outstanding land claims by 2009. Section 207 of the ALTAA required

"that the Secretary of the Interior "(1) review the withdrawals made pursuant to section 17(d)(1) of the Alaska Native Claims Settlement Act (43 U.S.C. 1616(d)(1)) to determine if any portion of the lands withdrawn pursuant to that provision can be opened to appropriation under the public land laws or if their withdrawal is still needed to protect the public interest in those lands; (2) provide an opportunity for public notice and comment, including recommendations with regard to lands to be reviewed under paragraph (1); and (3) submit to the Committee on Energy and Natural Resources of the Senate and the Committee on Resources of the House of Representatives a report that identifies any portion of the lands so withdrawn that can be opened to appropriation under the public land laws consistent with the protection of the public interest in these lands."

Although there are approximately 158,958,000 acres currently set aside by d-1 PLOs in Alaska, the Secretary's report to Congress (US Bureau of Land Management, 2006), formulated recommendations only for those 56,870,900 acres of lands under the administrative control of BLM. However, many of these BLM lands have also been selected by, but not yet conveyed to, the State of Alaska and/or Native Corporations. Approximately 20 million additional acres are expected to be eventually conveyed out of Federal ownership, although the ALTAA-established target date of 2009 is unlikely to be met. A list of regulations specific to the conveyance and resolution of Federal lands in Alaska is available at http://www.blm.gov/wo/st/en/info/regulations/alaska_specific_legislation.html

\section{Possible Outcomes}

The public lands affected by the d-1 PLOs and withdrawals discussed in the recent report to Congress (U.S. Bureau of Land Management, 2006) fall into three separate categories based on the consequences of any future Congressional or land management actions to rescind the withdrawals.

1) Some of the lands on which d-1 withdrawals could be lifted currently lie within Federal conservation system units (CSUs) such as National Wildlife Refuges or Monuments, or within other land use designations (e.g. military reservations) which preclude mineral entry. Most of these CSUs were established after ANCSA, and the effect of lifting a d-1 withdrawal would be null, since the later public land orders and designations would remain in effect. 2) Some Federal lands on which d-1 withdrawals could be lifted would revert to BLM management control, and could be opened to mineral entry or mineral leasing under future land management decisions; and 3) lands whose final status is uncertain because of unresolved land claims. The latter are Federal lands that have been selected by ANCSA Native corporations or the State of Alaska for possible inclusion into their land base. Some are the subject of competing claims. The lands with outstanding claims are subject to final prioritization by the State and Native corporations, scheduled by the ALTAA for 2008, and subsequent surveying and conveyance by the BLM. However, since both the State and Native village and regional corporations are over selected (have chosen more land than their final 
allowed allotment), an unknown percentage of these lands will eventually return to BLM control. This report discusses only lands in the latter two categories.

\section{USGS Role in Alaska Federal Lands}

The U.S. Geological Survey provides impartial scientific data and interpretations of the earth, its hazards and its resources to land managers, the public and policy makers. The Mineral Resources Program of the USGS is the sole Federal provider of information related to mineral commodities, production and consumption and mineral resource potential worldwide.

The USGS role in resources and public lands in Alaska is three-fold: we 1) provide detailed scientific data and analysis useful in the further evaluation and managment of these lands, 2) provide information, both qualitative and quantitative, on the known and undiscovered mineral resource potential of these lands, and 3) identify areas in which mineral exploration activities (sampling, geophysical surveys, staking, drilling etc.) are likely to occur. Section 1010(a) of ANILCA specifically requires that the Secretary of Interior

"shall, to the full extent of his authority, assess the oil, gas, and other mineral potential on all public lands in the State of Alaska in order to expand the data base with respect to the mineral potential of such lands."

Current understanding of geologic, geochemical and geophysical characteristics of the lands proposed for possible lifting of the d-1 land restrictions is very limited relative to areas in other states identified for possible changes in land status or land management. This interim report outlines some strategic actions which the USGS could undertake to strengthen the information base and decision making process for these $\mathrm{d}-1$ lands.

\section{Purpose of This Report}

This interim report follows from the June 2006 recommendations to Congress by the BLM concerning disposition of the d-1 lands. That report recommended lifting of a significant number of d-1 PLOs, through the ongoing land management process within the BLM (e.g. resource management planning areas), or through Congressional action.

The strategic actions outlined in this document refer only to Federal lands under US Bureau of Land Management (BLM) jurisdiction that 1) are affected by temporary withdrawals from mineral entry and mineral leasing by PLOs made pursuant to the Section 17(d)(1) of the ANCSA; 2) have been identified by the BLM as candidates for possible lifting of these PLOs and restrictions (U.S. Bureau of Land Management, 2006); and 3) lie outside of current Federal parks, preserves, monuments, refuges, reserves, wilderness areas and military installations that are closed to mineral entry, because within those areas the potential lifting of the d-1 restrictions has no practical effect.

The resulting lands discussed here comprise approximately $121,000 \mathrm{~km}^{2}$ (29.9 million acres) of Alaska (Table 1) that, pending final resolution of Native and State land claims, will or may remain under Federal (BLM) control, and could be opened to mineral entry. For the purposes of this report, only these 29.9 million acres will hereafter be referred to as "d-1" lands. 
Table 1. Ownership of d-1 lands in Alaska, pending settlement of Native and State land claims.

\begin{tabular}{|c|c|c|c|c|}
\hline & & \multicolumn{2}{|c|}{$\mathrm{km}^{2}$} & acres \\
\hline 1 & Areas which will definitely remain in BLM control & & 40,280 & $9,949,160$ \\
\hline $2 \mathrm{a}$ & Areas selected only by State of Alaska & 27,510 & & $6,794,970$ \\
\hline $2 b$ & Areas selected only by Native corporations & 52,130 & & $12,876,110$ \\
\hline $2 \mathrm{c}$ & Areas selected by both State and Native & 1,120 & & 276,640 \\
\hline 2 & Areas which may remain in BLM control $((2 a+b+c)$ & & 80,760 & $19,947,720$ \\
\hline \multicolumn{2}{|c|}{ Total d-1 land area $(=1+2)$} & 1 & 121,040 & $29,896,880$ \\
\hline
\end{tabular}

This report gives a brief overview of the spatial distribution and physiographic setting, mineral occurrences, and mineral resource potential of the d-1lands. It outlines further geoscience information which could be compiled, collected, and evaluated in order to make a more accurate and comprehensive examination of the potential for undiscovered, locatable mineral resources on these Federal lands. This information is intended to provide guidance to USGS program managers and Federal land managers on matters of future exploration, access needs, and consequences of land status changes.

\section{Identifying and evaluating d-1 lands}

We identified lands affected by d-1 PLO withdrawals in Alaska from digital datasets provided by the BLM (Appendix 1). Figure 1 indicates the location of these lands in red and blue. Some very small areas identified by this process may be artifacts (i.e. slivers) resulting from slight inaccuracies in the digital representations of various land parcel boundaries. As ongoing land selections are prioritized, surveyed and conveyed, the amount of land indicated in blue on Figure 1 will decrease gradually as lands pass out of Federal ownership.

[Figure 1 hyperlinked]

Figure 1. (oversized) Topographic map of mainland Alaska, showing extent of BLM d-1 lands (in red and blue); Federal Conservation System Units (CSUs) and other areas closed to mineral entry (in green); d-1 lands Areas of Interest identified in this report (lettered ovals); major towns and villages; $1^{\circ} \times 3^{\circ}$ quadrangle boundaries and names; and known mines, prospects and mineral occurrences (USGS, 2005) within the areas of interest.

The d-1 lands are scattered from $57^{\circ}$ to $71^{\circ} \mathrm{N}$ and across the width of mainland Alaska $(\sim 1500 \mathrm{~km})$. They span a wide range of physiographic provinces (Fig. 2), and a variety of maritime, boreal, and arctic climates. Most are remote from surface transportation; access is by air (e.g. floatplane, helicopter) or water only. 


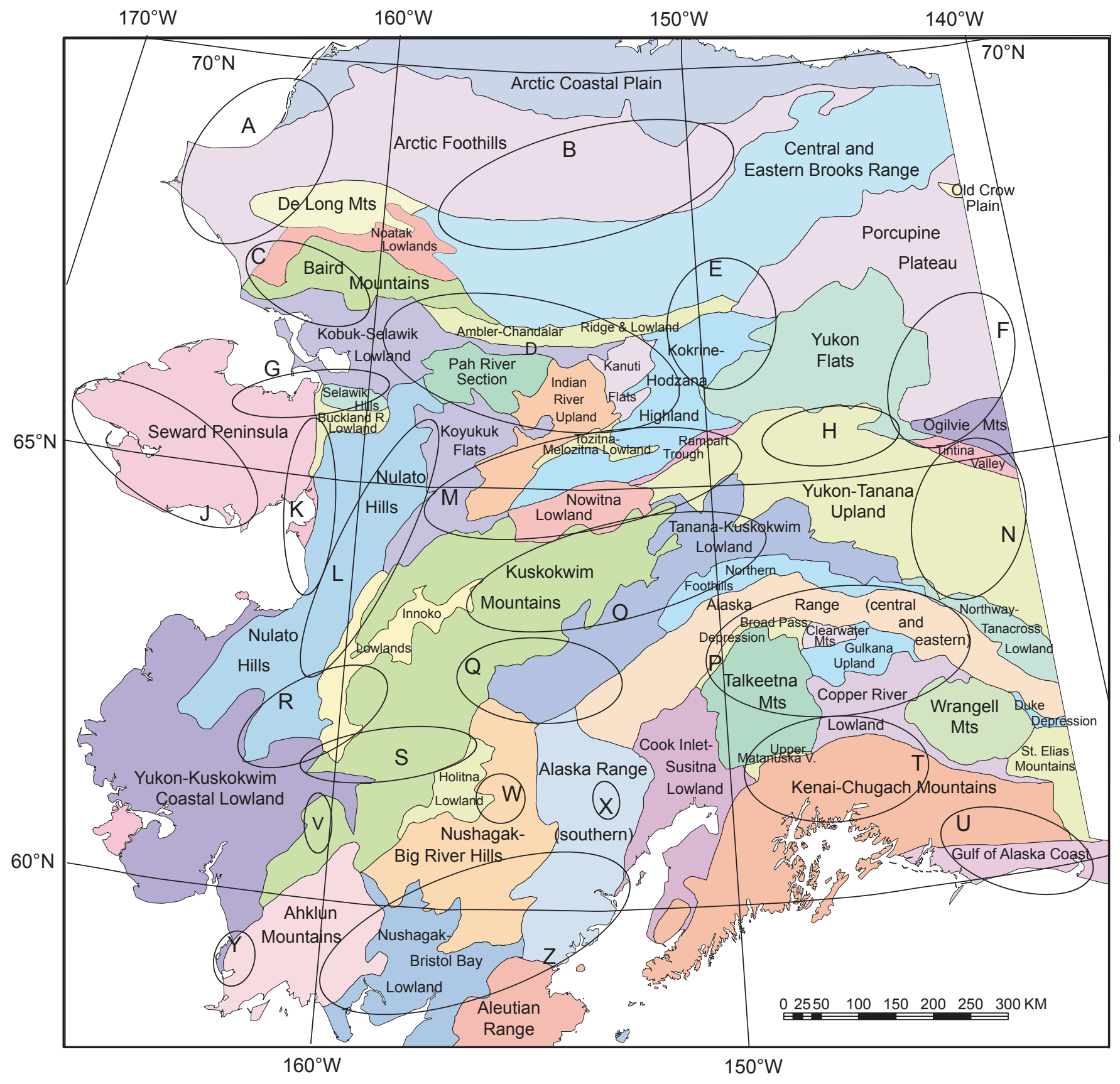

$65^{\circ} \mathrm{N}$

Figure 2. Map of mainland Alaska showing d-1 areas of interest (ovals) and labeled physiographic provinces as defined by Wahrhaftig (1994). 
Individual blocks affected by the land orders are as small as $0.5 \mathrm{~km}^{2}$ (120acres); contiguous blocks are as large as $5000 \mathrm{~km}^{2}$ (1.2 million acres). These 29.9 million acres occur in 73 separate $1^{\circ} \times 3^{\circ}(1: 250,000)$ quadrangles, comprising less than $7 \%$ of the area across which they are scattered. Many d-1 lands, however, fall into clusters.

Because the geologic units and conditions which control mineral deposit formation and exhumation are regional in nature, and because the geochemical and geophysical expression of these geologic settings extend beyond the immediate deposit, lands in close proximity to the dlands are an important contributor to evaluating their mineral resource potential.

We define 25 "Areas of Interest" (A-Z; Fig. 1) which contain a significant proportion of d-1 lands, and which, together, account for $>98 \%$ of d-1 lands. These areas of interest range from $1,410-57,600 \mathrm{~km}^{2}(0.35$ to 14.2 million acres) in size. They include State, Native, private, and BLM lands unaffected by d-1 withdrawals, but which may have increased exploration, access, or infrastructure interest in the future due to their proximity to d-1lands.

\section{Mineral deposits}

Regional geologic controls on mineral deposit formation can be evaluated at the broadest scale by examination of the bedrock geology (Beikman, 1980; Labay and others, 2006; Wilson and others, 1998, 1999, 2005a,b; 2006a,b). More accurate analysis of mineral resource potential requires detailed information on the unconsolidated surficial deposits and lithologies of bedrock within each area of interest. Historical mining districts in Alaska (Ransome and Kerns, 1954) form the basis for most Federal and State geologic studies of mineral deposits; their location and boundaries are illustrated in Figure 3. Previous summaries of mineral deposits in Alaska, useful for a preliminary evaluation of d-1 areas of interest include Berg and Cobb (1967), and Nokleberg and others $(1987,1994)$ for lode (bedrock) deposits, and Cobb (1973) and Yeend and others (1987) for placer (unconsolidated) deposits. Hughes and Szumigala (2006) provide a comprehensive summary of mineral exploration, development, and production activities in Alaska in 2005. Szumigala and Hughes (2007) provide preliminary information on 2006 activities; a full report for 2006 is expected to be published in early November 2007.

Information on all known past producers (ore deposits), explored prospects, and mineral occurrences is kept current by the Alaska Resource Data Files (ARDF) which are also available in a Google $^{\mathrm{TM}}$ Earth format (U.S. Geological Survey, 2005). Four hundred twenty two mines, prospects, and occurrences are known on d-1 lands in Alaska (Fig. 1.) Within the areas of interest (A-Z) outlined on Figure 1, the total number of mines, prospects, and occurrences reported to date is 2,460 . These figures are about $6 \%$ and $34 \%$, respectively of all current ARDF records (7219) statewide (U.S. Geological Survey, 2005). 


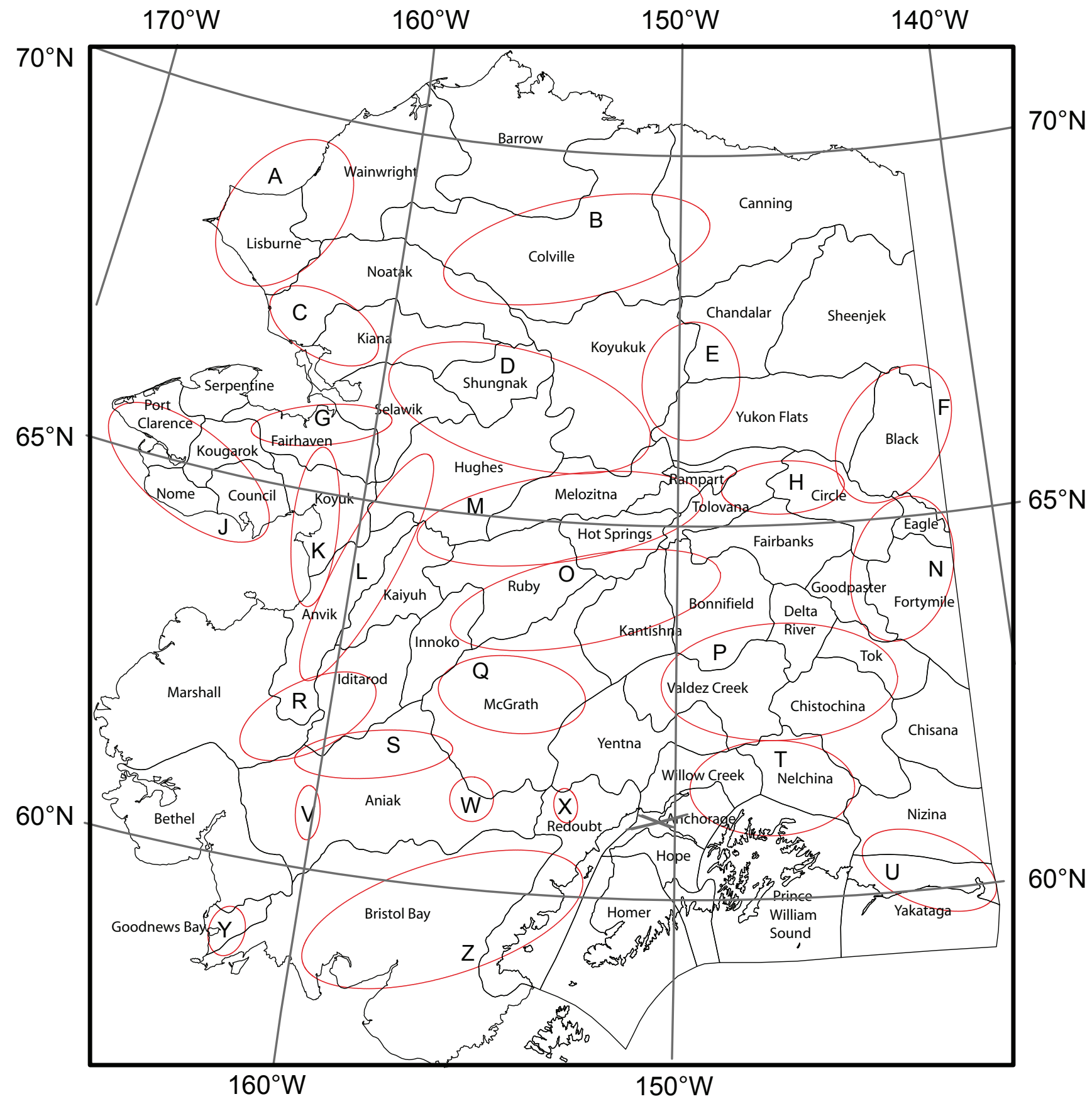

Figure 3. Map of mainland Alaska, showing $d-1$ areas of interest (red ovals) and labeled mining district boundaries and delineated by Ransome and Kerns (1954). 
Table 2. Mines, prospects, and mineral occurrences on d-1 lands and in Areas of Interest (data from Alaska Resource Data Files, USGS, 2005).

\begin{tabular}{|c|c|c|c|}
\hline $\begin{array}{c}\text { Area } \\
\text { (Fig. 1) }\end{array}$ & $\begin{array}{c}\text { No. of ARDF } \\
\text { records on d-1 } \\
\text { lands within Area }\end{array}$ & $\begin{array}{c}\text { No. of ARDF records } \\
\text { on all other land } \\
\text { types within Area }\end{array}$ & $\begin{array}{c}\text { Total number of known } \\
\text { mines, prospects and } \\
\text { mineral occurrences }\end{array}$ \\
\hline A & 1 & 16 & 17 \\
\hline B & 6 & 34 & 40 \\
\hline C & 2 & 20 & 22 \\
\hline D & 30 & 49 & 19 \\
\hline E & 26 & 97 & 21 \\
\hline F & 4 & 17 & 48 \\
\hline G & 10 & 38 & 80 \\
\hline H & 5 & 75 & 617 \\
\hline J & 51 & 566 & 41 \\
\hline K & 10 & 31 & 6 \\
\hline L & 1 & 5 & 168 \\
\hline M & 38 & 130 & 192 \\
\hline N & 81 & 111 & 52 \\
\hline O & 40 & 12 & 899 \\
\hline P & 50 & 349 & 18 \\
\hline Q & 3 & 84 & 70 \\
\hline R & 3 & 15 & 194 \\
\hline S & 15 & 55 & 19 \\
\hline T & 33 & 161 & 25 \\
\hline U & 0 & 19 & 3 \\
\hline V & 3 & 22 & 0 \\
\hline W & 1 & 2 & 41 \\
\hline X & 0 & 0 & 98 \\
\hline Y & 4 & 37 & $\mathbf{2 4 6 0}$ \\
\hline Z & 5 & 93 & \\
\hline Total & $\mathbf{4 2 2}$ & 2038 & \\
\hline & & & \\
\hline
\end{tabular}

Mineral deposits are generally characterized and referred to as deposit types of models (e.g. Cox and Singer, 1986), and explored for according to their geologic properties. For simplicity in this preliminary presentation of data, we have grouped individual deposit models into categories (Table 3) with similar element suites, lithologic or geologic properties. These groups are separately symbolized on Figure 1. 
Table 3. Mineral deposit types referenced in this report

\begin{tabular}{|l|l|}
\hline \multicolumn{1}{|c|}{$\begin{array}{c}\text { Name of Group } \\
\text { (Fig. 1) }\end{array}$} & \multicolumn{1}{|c|}{$\begin{array}{c}\text { Individual mineral deposit models (identified by model number, } \\
\text { Cox and Singer, 1986) included in group }\end{array}$} \\
\hline Placer gold & $39 \mathrm{a}$ \\
\hline Placer, other commodities & $39 \mathrm{~b}, 39 \mathrm{c}, 39 \mathrm{e}$ \\
\hline Gold-bearing veins & $25 \mathrm{~b}, 25 \mathrm{c}, 25 \mathrm{~d}, 25 \mathrm{e}, 36 \mathrm{a}, 36 \mathrm{~b}$ \\
\hline Mercury & $27 \mathrm{a}, 27 \mathrm{~b}, 27 \mathrm{c}$ \\
\hline Tin, tungsten deposits & $14 \mathrm{a}, 14 \mathrm{~b}, 14 \mathrm{c}, 15 \mathrm{a}, 15 \mathrm{~b}, 15 \mathrm{c}, 20 \mathrm{a}, 20 \mathrm{~b}, 21 \mathrm{c}$ \\
\hline Uranium, thorium deposits & $11 \mathrm{~d}, 25 \mathrm{f}, 30 \mathrm{c}, 32 \mathrm{e}, 37 \mathrm{a}$ \\
\hline $\begin{array}{l}\text { Mafic--/ ultramafic- rock-associated } \\
\text { nickel, copper, platinum group elements }\end{array}$ & $5 \mathrm{a}, 5 \mathrm{~b}, 6 \mathrm{a}, 6 \mathrm{~b}, 7 \mathrm{a}, 7 \mathrm{~b}, 8 \mathrm{a}, 8 \mathrm{~b}, 8 \mathrm{c}, 8 \mathrm{~d}, 8 \mathrm{f}, 8 \mathrm{~g}, 9$ \\
\hline Porphyry copper, molybdenum, \pm gold & $17,18 \mathrm{a}, 20 \mathrm{c}, 21 \mathrm{a}, 21 \mathrm{~b}$ \\
\hline Skarns, base metal and iron & $18 \mathrm{~b}, 18 \mathrm{c}, 18 \mathrm{~d}$ \\
\hline $\begin{array}{l}\text { Sediment-hosted (base-metal, iron, } \\
\text { phosphate, barite) }\end{array}$ & $31 \mathrm{a}, 31 \mathrm{~b}, 34 \mathrm{a}, 34 \mathrm{~b}, 34 \mathrm{c}$ \\
\hline Stratabound base metal & $30 \mathrm{a}, 30 \mathrm{~b}, 32 \mathrm{a}, 32 \mathrm{~b}, 32 \mathrm{c}$ \\
\hline Polymetallic vein and replacement & $19 \mathrm{a}, 22 \mathrm{c}$ \\
\hline Volcanogenic massive sulfide & $24 \mathrm{a}, 24 \mathrm{~b}, 28 \mathrm{a}$ \\
\hline Other / miscellaneous & $10,16 \mathrm{a}, 23,24 \mathrm{c}, 25 \mathrm{a}, 25 \mathrm{~g}, 26 \mathrm{a}, 27 \mathrm{~d}, 38 \mathrm{a}$ \\
\hline No deposits model designated & No model number assigned in ARDF record \\
\hline
\end{tabular}

Cox and Singer (1986), Eckstrand and others (1995), and Hedenquist and others (2005) provide further information and details concerning mineral deposit models and types. Additional information on deposit models applicable to Alaska is found in Goldfarb and Miller (1997), U.S. Geological Survey (2000) and Fonseca and Bradshaw (2005).

\section{Strategic actions to improve geologic understanding of d-1 lands}

If additional Federal lands in Alaska are opened to mineral entry in the future, the impact on any given parcel of land could range from low (e.g. airborne surveys, surface sampling) to high (e.g. drilling or mining). These impacts, occurring under whatever regulatory framework is in effect at the time, are also highly dependent on the access to, and geologic conditions of, the parcel of land. The most effective predictor of likely exploration in an area would be the mineral resource potential of the area as perceived by the mineral exploration industry. This potential is usually expressed as the suitability of a given area to host a specific mineral deposit type (e.g. copper skarns), whose conditions are defined by the geologic setting (e.g. limestones in proximity to a granitic intrusion). This suitability is judged by comparing characteristics of known mineral occurrences nearby (if any), the regional and local bedrock and surficial geology, geochemistry, and geophysical signatures, with features of the deposit model of interest. Undiscovered mineral resource potential can also be addressed through a three-step assessment process such as that defined by the U.S. Geological Survey (Singer, 1993).

Most of the d-1 lands, and the areas of interest enclosing them, have undergone only reconnaissance or regional-scale geologic or mineral-related investigation. Because many are 
scattered parcels between other land designations, the evaluation actions suggested here should be completed for somewhat larger geographic domains with a relatively high proportion of d-1 lands, such as the areas of interest defined in Figure 1. Future actions could involve both off-site and onsite studies. In most cases, full evaluation of existing data (off-site) would be a prerequisite to the design of further remote or on-site studies. On-site investigations could be targeted to somewhat more geographically limited areas, but the realities of land access and sampling methods (e.g. downstream drainage geochemistry) necessitate that some non-d-1 lands be involved in most proposed on-site investigations as well. Scientific studies related to the hydrology, vegetation, and fauna of the areas of interest, if needed, could proceed by a series of steps similar to Actions 1 through 4 listed below. These actions are listed in a suggested chronologic sequence which proceeds from basic to most detailed information gathered, and from lowest-to highest- impact on the lands.

\section{Action 1) Compile data related to access, infrastructure, and land use}

Detailed (section-level), current land status / land claims maps

Villages / population distribution

Airports / landing strip database

Roads and conditions (State, local, trails, right-of-way easements, etc.)

Rivers, navigability, and port facilities

Railroads

Current Mineral Activity (Federal claims, State claims, State prospecting sites; activities on Native lands, etc.)

\section{Action 2) Compile and evaluate existing geoscience data}

The next step in evaluation of mineral resource potential of d-1 lands is compilation and evaluation of all existing geoscience data for the areas of interest. This includes two primary types of data: 1) that collected through on-site work on the d-1 lands and 2) that collected remotely (e.g. airborne, satellite) which may cover individual parcels of d-1 land. Many basic geoscience datasets are maintained by the USGS. Some areas have additional, more extensive and detailed data available through the Alaska Division of Geology and Geophysical Surveys (ADGGS) and other State agencies, the University of Alaska, regional Native corporations, and private industry. Careful examination of these data may reveal previously unknown samples or stations collected on or near individual d-1 lands parcels. The quality, quantity, completeness, accuracy of these reports should be evaluated during this phase.

A) Existing samples or information collected on and near d-1 lands

Ground-based geophysics

Gravity maps produced from past exploratory and regional measurements

Magnetotelluric data

Seismic data (reflection and/or refraction)

Ground-based electrical or electromagnetic data (e.g. VLF, max-min) 
Ground-based geochemical data

Soil and surficial materials

Lake and stream sediment samples

Stream sediment concentrates (may include data on both chemistry and mineralogy)

Lithogeochemical (bedrock) samples

Biogeochemical samples (vegetation, fish livers, moose droppings, etc.)

Mineral occurrences (e.g. ARDF, MAS-MILS)

Geologic maps (1:250,000, 1:63,360, detailed)

B) Existing, remotely-collected data which overlies d-1 lands

Topographic data (e.g. DLG, DRGs, DEMs, LIDAR)

Airborne data and imagery

Magnetics

Radiometrics (gamma-ray spectrometry)

Electromagnetics

Gravity

Radar (e.g. SLAR)

Photography

Satellite -based data and imagery

Multispectral (infrared, thermal, visible) (e.g. LANDSAT 5/7)

Radar (e.g. RADARSAT)

Radiometrics (e.g. MODIS, AVHRR)

Hyperspectral (e.g. ASTER, SPOT)

This compilation phase should produce for each of the areas examined: 1) as detailed as possible maps of the bedrock and surficial geology, and lithology of the d-1 lands and their immediate vicinity, and 2) a comprehensive report that identifies the geologic setting and controls of known mineral occurrences, summarizes the potential for specific mineral commodity- and deposit- types, and outlines a plan of action for further, more intensive studies, discussing the costs and benefits of off-site/ remote data collection and site-specific investigations.

\section{Action 3) Follow-up: off-site/ remote investigations}

Off-site investigations of d-1 lands could contribute limited information on physical properties (e.g. reflectance, density) of the surficial materials and bedrock in the region, but would provide little information on subsurface mineral resources themselves, unless those were associated with a unique attribute observable remotely (e.g. alteration of vegetative cover). Remote methods which might provide useful information include: 
Airborne geophysical methods

Radiometric surveys (gamma-ray spectrometry)

Magnetic surveys

Gravity surveys

Electromagnetic surveys (e.g. EM, TEM)

Radar( e.g. SLAR)

Aerial photography

Satellite-based methods

Multispectral (infrared, visible, thermal) (e.g. LANDSAT)

Radar (e.g. RADARSAT.)

Radiometrics (e.g. MODIS, AVHRR)

Hyperspectral data (e.g. ASTER, SPOT)

\section{Action 4) Follow-up: on-site investigations}

The most direct information on mineral resources of d-1 lands would be provided by on-site investigations. These evaluations would involve geologic and mineral occurrence mapping, measurements of physical properties, and collection of new samples (i.e. for geochemical analysis) which would further our understanding of the geologic framework, weathering characteristics, and mineral resource potential of the $\mathrm{d}-1$ lands.

Geochemical evaluation

Lithogeochemistry of background materials, altered and mineralized rocks

Drainage geochemical sampling; stream and lake sediments, bulk or panned concentrates, etc.

Mineralogy of glacial and drainage concentrates

Soil chemistry

Biogeochemical surveys

Geophysical evaluation

Spectral measurements of surficial, bedrock and mineralized materials

Gravity surveys

Electromagnetic and magnetic surveys (VLF, MT, etc.)

Mapping

Geological materials (surficial and bedrock)

Vegetative cover

Soil characteristics

Detailed examination of mineral occurrences 


\section{Summary Statement}

In conclusion, the USGS can improve understanding of the mineral resources and mineral potential of d-1 lands through a combination of off- and on-site investigations. These evaluations will provide information about known and undiscovered mineral resources, and will identify areas in which mineral exploration activities are likely to occur. This information will allow landmanagers to make more informed decisions about lifting any withdrawals on these lands. Individual areas targeted for followup can be prioritized to meet the goals of the Alaska Land Transfer Acceleration Act, land management agency needs, or critical mineral supply priorities of the Nation.

\section{Acknowledgments}

We thank Chad Hulse and Nora Shew for their timely preparation of maps and figures from a variety of source data. Reviewers Tom Light and Christina Neal provided valuable comments to improve both figures and text.

\section{References Cited}

Beikman, Helen, 1980, compiler, Geologic Map of Alaska: U.S. Geological Survey, 1:2,5000,000 scale, 2 sheets.

Berg, H.C., and Cobb, Edward, 1967, Metalliferous Lode Deposits of AK, USGS Bulletin 1246, $254 \mathrm{p}$.

Cobb, E.H., 1973, Placer Deposits of Alaska: U.S. Geological Survey Bulletin 1374, 213p.

Cox, D.P., and Singer, D.A., eds., 1986, Mineral deposit models: U.S. Geological Survey Bulletin $1693,379 \mathrm{p}$.

Eckstrand, O.R., Sinclair, W.D., and Thorpe, R.I., eds., 1995, Geology of Canadian Mineral Deposit Types: Geology of Canada, no.8,: Volume P-1 of Geological Society of America DNAG, Decade of North America Geology, Geology of North America, 640p, 1 plate.

Fonseca, A., and Bradshaw, G., eds., 2005, Yukon mineral deposit profiles: Yukon Geological Survey Open File Report 2005-5, 175 p. http://www.geology.gov.yk.ca./publications/openfile/2005/0f2005_5.pdf

Goldfarb, R.J., and Miller, L.D., eds.,, 1997, Mineral Deposits of Alaska: Economic Geology Monograph 9, 482p.

Hedenquist, J.W., Thompson, J.F.H., Goldfarb, R.J., and Richards, J.P., eds., 2005, Economic Geology One Hundredth Anniversary Volume: Society of Economic Geologists Inc., Littleton, Colorado, 1136p, 1 CD-ROM.

Hughes, R.A., and Szumigala, D.J., 2006, Alaska's Mineral Industry 2005,Alaska Division of Geological and Geophysical Surveys Special Report 60, 81p.

Labay, K.A., Crews, Jesse, Wilson, F.H., Shew, Nora, and Hults, C.K., 2006, Digital datasets for geologic map by Till, A.B., Dumoulin, J.A., Phillips, J.D., Stanley, R.G., and Crews, Jesse: Preliminary integrated geologic map databases for the United States: Digital data for the generalized bedrock geologic map, Yukon Flats region, east-central Alaska, U.S. Geological Survey Open-File Report 2006-1304, http://pubs.usgs.gov/of/2006/1304/

Nokleberg, W.J., Brew, D.A., Grybeck, D., Yeend, W., Bundtzen, T.K., Robinson, M.S., Smith, T.E., Berg, H.C., and contributions by 33 others, 1994, Metallogeny and major mineral deposits 
of Alaska, in Plafker, G., and Berg, H.C., eds., The Geology of Alaska: Boulder, Colorado, Geological Society of America, The Geology of North America, v. G-1., p. 855-904, 1 sheet.

Nokleberg, W.J., Bundtzen, T.K., Berg, H.C., Brew, D.A., Grybeck, D., Robinson, M.S., Smith,

T.E., and Yeend, W., 1987, Significant metalliferous lode deposits and placer deposits of Alaska:

U.S. Geological Survey Bulletin 1786, 104p., 2 plates.

Ransome, A.L., and Kerns, W.H., 1954, Names and definitions of regions, districts and subdistricts in Alaska: U.S. Bureau of Miners Information Circular 7679, 91p.

Singer, D.A., 1993, Basic concepts in three-part quantitative assessments of undiscovered mineral resources: Nonrenewable Resources, v. 1, no. 1, p. 97-106.

Szumigala, D.J., and Hughes, R.A., 2007, Alaska's Mineral Industry 2006: A Summary, Alaska Division of Geological and Geophysical Surveys Information Circular 54, 20p.

US Bureau of Land Management, 2006, Section 207 Alaska Land Transfer Acceleration Act: A Review of D-1 Withdrawals, U.S. Dept. of Interior, Bureau of Land Management Report to Congress, June, 22006. Prepared by David Mushovic \& Susan Lavin, BLM Alaska State Office, 125p. BLM/AK/AD-06/007+2355+932, http://www.blm.gov/ak/ak930/207report/index.html

U.S. Geological Survey, 2000, 1998 assessment of undiscovered deposits of gold, silver, copper, lead and zinc in the United States: U.S. Geological Survey Circular 1178, 21 p., 1 CD-ROM US Geological Survey, 2005, Alaska Resource Data File (ARDF): http://ardf.wr.usgs.gov/

Wahrhaftig, Clyde, 1994, Map of physiographic divisions of Alaska, Plate 2 in Plafker, George, and Berg, H.C., eds., The geology of Alaska, Boulder, Colorado, Geological Society of America, Geology of North America, v. G1, 1 sheet, scale 1:2,500,000.

Wilson, F.H., Detterman, R.L., and Dubois, Gregory, 1999, Digital data for the geologic framework of the Alaska Peninsula, southwest Alaska, and the Alaska Peninsula terrane: U.S. Geological Survey Open-File Report 1999-317, http://geopubs.wr.usgs.gov/open-file/of99-317/

Wilson, F.H., Dover, J.H., Bradley, D.C., Weber, F.R., Bundtzen, T.K., and Haeussler, P.J., 1998, Geologic Map of Central (Interior) Alaska, U.S. Geological Survey Open-File Report 98-133A/B, 3 plates, scale 1:500,000, 63p, http://pubs.usgs.gov/of/1998/of98-133-a/

Wilson, F.H., Labay, K.A., Shew, N.B., and Hults, C.K., 2006a, Digital datasets for geologic map by Patton, W.W. Jr., Wilson, F.H., and Labay, K.A.: Preliminary integrated geologic map databases for the United States: Digital data for the reconnaissance geologic map of the lower Yukon River region, Alaska: U.S. Geological Survey Open-File Report 2006-1292, http://pubs.usgs.gov/of/2006/1292/

Wilson, F.H., Labay, K.A., Shew, N. B., and Mohadjer, Solmaz, 2005a, Digital datasets for geologic map by Patton, W.W., Jr., Wilson, F.W., Labay, K.A., and Shew, N.B., Preliminary integrated geologic map databases for the United States: Digital Data for the Reconnaisance Geologic Map of the Yukon-Koyukuk Basin, Alaska, U.S. Geological Survey Open-File Report 2005-1341, http://pubs.usgs.gov/of/2005/1341/

Wilson, F.H., Labay, K.A., Shew, N. B., Preller, C.C., and Mohadjer, Solmaz, 2005b, Digital datasets for geologic map by Richter, D.H., Preller, C.D., Labay, K.A., and Shew, N.B., Preliminary Integrated Geologic Map Databases for the United States: Digital Data for the Geology of Wrangell-Saint Elias National Park and Preserve, Alaska, U.S. Geological Survey Open-File Report 2005-1342, http://pubs.usgs.gov/of/2005/1342/

Wilson, F.H., Mohadjer, Solmaz, Labay, K.A., and Shew, Nora, 2006b, Digital datasets for geologic map by Wilson, F.H., Blodgett, R.B., Blome, C.D., Mohadjer, Solmaz, Preller, C.C., Klimasauskas, E.P., Gamble, B.M., and Coonrad, W.L.: Preliminary Integrated Geologic Map Databases for the United States: Digital Data for the Reconnaissance Bedrock Geologic Map for 
the Northern Alaska Peninsula area, Southwest Alaska: U.S. Geological Survey Open File Report 2006-1303, on-line only. http://pubs.usgs.gov/of/2006/1303/

Yeend, Warren, Bundtzen, T.K., and Nokleberg, W.J., 1987, Significant placer deposits of Alaska, in Nokleberg, W.J., Bundtzen, T.K., Berg, H.C., Brew, D.A., Grybeck, Donald, Robinson, M.S., Smith, T.E., and Yeend, Warren, Significant metalliferous lode deposits and placer districts of Alaska: U.S. Geological Survey Bulletin 1786, p. 73-82.C.

\section{Appendix 1: Procedures used for delineating d-1 lands from BLM GIS databases}

In order to determine the location and extent of d-1 lands remaining in Alaska that might be subject to d-1 PLO-related changes in status or mineral entry, we used two unpublished digital files from by the Bureau of Land Management. The first digital file was an Arc shapefile named "genstat.shp", obtained from the BLM on 9/8/2006. Its metadata file reads: "This dataset contains generalized land status pattern for Alaska with respect to Federal, State, and Native Lands. The Land Status attributes are a snapshot of the Land Information System Database and are only accurate as that database. The data is [sic] produced to the section (square mile) level."

The second digital file, an Arc geodatabase named "D1_Wdl.mdb" contains a polygon feature class "D1_wdls_no_conveyence", which the metadata file indicates was last updated on 9/14/2006. According to the "Read me" file accompanying the digital file: "This [sic] data includes all remaining, unconveyed Federal lands affected by the D-1 PLO's including Conservation System Units (CSUs) and land under PLO5180 which kept metalliferous entry available. The file is organized based on overlapping PLO areas, and where numerous PLO's overlap, the most restrictive withdrawal type is listed as data field "dominant_PLO"."

\section{Step 1: Identifying the BLM lands with d-1 withdrawals}

From the "genstat" shapefile, all polygons with a value of "y" in the "blm" attribute field were extracted into a new layer. This limited our selection to only lands under the control of the BLM, effectively excluding all CSUs, and lands under the control of other Federal entities (e.g. U.S. Army). Using only these BLM=yes polygons, the" D1_wdls_no_conveyence" polygon feature class in the geodatabase was clipped to remove any areas that fell outside the BLM lands. In the remaining D1 areas if there was a " $y$ " in the "plo5180" field then those polygons were deleted as well. This is because PLO 5180 allows mineral entry, so any potential lifting of d- 1 related PLOs would not effectively change the status of lands already impacted by PLO 5180.

\section{Step 2: Identifying areas with unresolved State and/or Native land selection}

From the "genstat" shapefile, all polygons with an attribute of "y" in the "ss" (stateselected) or "ns" (native-selected) attribute fields were extracted into a new layer. This identified land selections chosen by either the State of Alaska or a native regional or village corporation, but which, as of 9/2006, had not yet been patented, tentatively approved, or interim conveyed.

If a polygon had a State or native selection but was also attributed as "y" in "mil" (military), "fs" (Forest Service), "nps" (National Park Service), or "fws" (Fish and Wildlife Service), then those polygons were deleted. This was because if the land failed to be conveyed or patented, then control would revert to a Federal agency other than the BLM. 
Using these extracted polygons, the "D1_wdls_no_conveyence" polygon feature class in the geodatabase was clipped to remove any areas that fell outside the areas with selections (i.e. would automatically remain in BLM control and had been identified in Step 1 above). In the remaining D1 areas, if there was a "y" in the "plo5180" field then those polygons were deleted as well, because the open-to-mineral entry status of lands affected by PLO 5180 would not be affected by d-1 PLO decisions.

\section{Results}

The above procedures extracted the polygons indicated in red and blue on Figure 1. Areas shown in red are those affected by d-1 PLOs which will definitely remain under BLM jurisdiction. Areas shown in blue are those affected by d-1 PLOs that may revert to BLM jurisdiction after resolution of outstanding State and Native claims. We obtained a second "general land status" spatial dataset from the Alaska Division of Natural Resources Geospatial Data Clearinghouse website (http://www.asgdc.state.ak.us/) in November 2006. We used this update to make minor corrections to our files to remove any polygons that had been patented or interim conveyed between September and November 2006. 